\title{
Earth First? CERCLA Reimbursement Claims and Bankruptey
}

\author{
Daniel Klerman†
}

The Comprehensive Environmental Response, Compensation and Liability Act (CERCLA) establishes a statutory regime for cleaning up sites contaminated by hazardous wastes. ${ }^{1}$ At the core of CERCLA, the liability provisions allow the Environmental Protection Agency to demand reimbursement from a variety of private parties for costs incurred in decontaminating polluted sites. ${ }^{2}$ Most importantly, CERCLA allows recovery from the current owner of the polluted site, regardless of that party's actual contribution to the contamination of the land. ${ }^{3}$

Owners of polluted land, however, sometimes become insolvent and seek the protection of the bankruptcy laws. ${ }^{4}$ Courts must then decide to what extent the EPA can recover expenses from an owner in bankruptcy. This question is most difficult when the hazardous substances are released before the filing of the bankruptcy petition, but the EPA does not seek reimbursement until after the bankruptcy proceeding has begun.

In pursuing reimbursement, the EPA is normally an unsecured creditor. ${ }^{5}$ Unsecured creditors share pro-rata in the distribution of assets. ${ }^{6}$ The assets distributed, however, are usually worth far less than the outstanding claims, often resulting in payment of only ten or twenty percent of the face value of the claims. ${ }^{7}$ Because of this,

$\dagger$ B.A. 1988, Yale University; J.D. Candidate 1991, Ph.D Candidate, The University of Chicago.

142 USC $\$ 9601$ et seq (1988).

2 Id at $\$ 9607$. CERCLA also allows state environmental agencies and private parties to demand reimbursement. Id at $\$ 9607$ (a)(4)(A), (B). For convenience, this Comment assumes the EPA seeks reimbursement. Most of the arguments presented here, except those in Section IV, apply equally well to reimbursement claims by states and private parties.

s Id at § 9607(a)(1).

- This Comment focuses on corporate debtors. Most of the conclusions also apply to individual debtors, although the "fresh start" policy for such debtors might suggest an analysis of the bankruptcy discharge different from that presented in Section III.B.

- See text at note 59.

- 11 USC \& 726(b) (1988).

7 One recent survey of thirty large reorganizing firms documents several examples of payments of less than fifteen percent of face value. Julian R. Franks and Walter N. Torous, An Empirical Investigation of U.S. Firms in Reorganization, $44 \mathrm{~J}$ Fin 747, 755 (1989). 
the EPA has requested administrative expense priority, which would give it a right superior to most unsecured claimants. Most courts have granted the EPA this priority. ${ }^{8}$ This Comment criticizes the conclusions and reasoning of these courts and suggests that CERCLA reimbursement claims are best treated as ordinary unsecured claims. The Comment emphasizes, however, that even if courts treat the EPA's claims for reimbursement of cleanup expenses as ordinary unsecured claims, CERCLA's liability and lien provisions suggest that the EPA will be able to receive additional funds. There are three potential sources for such funds: subsequent purchasers of the polluted property, if the firm liquidates; the firm, if it reorganizes and retains the property; or the property itself, if the property is abandoned or excluded from the reorganization plan.

Some courts and commentators have approached the question of CERCLA reimbursement priority as a conflict between environmental law and bankruptcy law-environmental law imposing obligations in the interest of protecting the planet, and bankruptcy diluting those obligations in the interest of preserving assets for equitable distribution to creditors. ${ }^{9}$ This Comment rejects that approach. Instead of analyzing the problem in terms of a conflict between bankruptcy and environmental law, this Comment asks where CERCLA obligations fit into the bankruptcy priority scheme. It does not deny that Congress could set a different priority, but rather considers the priority of CERCLA obligations given current law.

Section I outlines the basic features of CERCLA and the Bankruptcy Code, and discusses the approach taken by most courts in analyzing the priority of CERCLA reimbursement claims. Section II argues that CERCLA reimbursement claims arising out of prepetition releases should be treated as ordinary unsecured claims. Courts should reserve administrative expense priority for

\footnotetext{
B See, for example, In re Wall Tube \& Metal Products Co., 831 F2d 118 (6th Cir 1987); In re Stevens, 68 Bankr 774 (D Me 1987); In re Chateaugay Corp., 112 Bankr 513, 525 (Bankr S D NY 1990); In re Better-Brite Plating, 105 Bankr 912 (Bankr E D Wis 1989); In re Peerless Plating, 70 Bankr 943, 948-49 (Bankr W D Mich 1987); In re Mowbray Engineering, 67 Bankr 34, 36 (Bankr M D Ala 1986); In re T.P. Long Chemical, Inc., 45 Bankr 278, 282-87 (Bankr N D Ohio 1985). In two cases involving private party plaintiffs, the reimbursement claims were treated as ordinary unsecured claims. In re Dant \& Russell, Inc., 853 F2d 700, 708 (9th Cir 1988); Southern Railway Co. v Johnson Bronze Co., 753 F2d 137, 141 (3d Cir 1985).

- See, for example, Ellen Sward, Resolving Conflicts Between Bankruptcy Law and the State Police Power, 1987 Wis L Rev 403; Penn Terra v Dept. of Environmental Resources, 733 F2d 267, 269 (3d Cir 1984).
} 
claims arising out of the trustee's management of the firm's assets; they should not give such priority to claims that existed before the trustee took control. Section III demonstrates how CERCLA's lien and liability provisions should enable the EPA to gather additional funds for cleanup. Section IV argues that CERCLA administrative orders and injunctions ought to be stayed. These powers are merely alternative ways for the EPA to shift the cost of cleanup to the bankrupt firm. In using them, the EPA acts as a creditor, not a regulator, and therefore is not entitled to the police power exception to the automatic stay.

\section{The Legal Framework}

\section{A. CERCLA}

Congress passed CERCLA in 1980. CERCLA authorizes the President-who has delegated his power to the EPA-to establish cleanup priorities for environmental hazards and to decontaminate high priority sites. ${ }^{10}$ To finance these efforts, Congress established a "Superfund," financed by taxes on chemical feedstocks, petroleum, and general corporate profits. ${ }^{11}$ Once the EPA completes cleanup, the process of sorting out liability commences. CERCLA liability is broad, and includes the current owner of the land and the owner at the time of the disposal of the hazardous substances. $^{12}$ In this way, CERCLA is significantly different from other environmental protection statutes, such as the Resource Conservation and Recovery Act ${ }^{13}$ or the Clean Air Act. ${ }^{14}$ While those statutes attempt to reduce environmental damage by regulating potential polluters, CERCLA attempts to remedy preexisting pollution by empowering the EPA to take direct action and recoup its costs later. ${ }^{15}$ CERCLA also authorizes the EPA to procure injunctions and issue administrative orders requiring abatement of danger in cases where there "may be an imminent and substantial endangerment to the public health or welfare or environment."16

20 42 USC $\S 9604(\mathrm{a}), 9605$.

11 Id at $\$ 9611$.

12 Id at $\$ 9607(\mathrm{a})$.

1s Id at $\$ 6901$ et seq (1988).

14 Id at $\$ 7401$ et seq (1990).

15 See State of New York v Shore Realty Corp, 759 F2d 1032, 1041 (2d Cir 1985) ("In sum, CERCLA is not a regulatory standard-setting statute such as the Clean Air Act. Rather the government generally undertakes pollution abatement, and polluters pay for such abatement through tax and reimbursement liability.") (citations omitted).

16 42 USC $\S 9606(a)$. 
In 1986, Congress enacted a number of amendments designed to strengthen CERCLA, ${ }^{17}$ including a provision giving the EPA a lien on the property undergoing cleanup..$^{18}$ That lien, however, arises at or after the time the EPA incurs cleanup expenses and is junior to any preexisting liens.

Although CERCLA originally envisioned that the EPA would conduct most of the cleanup itself and later recover from responsible parties, this approach proved unworkable. Superfund assets were simply inadequate to support the luxury of spending now and collecting later. ${ }^{19}$ The EPA has responded to this problem by the aggressive use of administrative orders and injunctions. The courts have facilitated the use of these remedies by liberally interpreting the "imminent and substantial endangerment" requirement. Essentially, the courts have found an imminent and substantial danger whenever hazardous substances have been released, even if the feared harm may not materialize for several years. ${ }^{20}$ In doing so, they have converted what was originally intended as an emergency provision into a tool for routine use, whose primary function is protecting the solvency of the Superfund..$^{21}$ This shift is evident in the EPA's current policy of using administrative orders first and only turning to the Superfund if those orders fail. ${ }^{22}$

\section{B. Bankruptcy Law}

Bankruptcy law seeks to provide an orderly process for debtors in financial difficulty to satisfy their creditors. Debtors in bankruptcy may liquidate (usually under Chapter 7 of the Bankruptcy $\mathrm{Code}^{23}$ ) or reorganize (usually under Chapter $11^{24}$ ). Bankruptcy

\footnotetext{
17 Superfund Amendments and Reauthorization Act of 1986 (SARA), Pub L No 99-499, 100 Stat 1613 (1986), codified as an amendment to CERCLA, 42 USC $\S \$ 9601-9675$.

1842 USC \$ 9604(1).

19 United States Environmental Protection Agency, A Management Review of the Superfund Program 1-7 (June 1989). The EPA is authorized to spend only $\$ 8.5$ billion per year from the Superfund, while the cost of cleaning up all contaminated sites is estimated at between $\$ 100$ and $\$ 700$ billion. Frederick R. Anderson, Daniel R. Mandelker, and A. Dan Tarlock, Environmental Protection: Law and Policy 614, 617 (Little, Brown, 2d ed 1990).

${ }^{20}$ See, for example, United States v Ottati \& Goss, Inc., 630 F Supp 1361, 1394 (D NH 1985) ("An 'imminent hazard' may be declared at any point in a chain of events which may ultimately result in harm to the public.") (emphasis added); United States $v$ Conservation Chemical Co., 619 F Supp 162, 193 (W D Mo 1985); United States v Seymour Recycling Corp., 618 F Supp 1, 5 (S D Ind 1984).

${ }^{21}$ Anderson, Mandelker, and Tarlock, Environmental Protection at 660-62 (cited in note 19).

${ }^{22}$ EPA, A Management Review of the Superfund Program at 2-6 (cited in note 19).

2s 11 USC $\$ 701$ et seq (1988).

${ }^{24}$ Id at $\S 1161$ et seq.
} 
proceedings commence with the filing of a petition with the bankruptcy court. ${ }^{25}$ Either the debtor, or if the debtor is insolvent, a coalition of creditors meeting certain conditions, may file the petition. ${ }^{26}$ In Chapter 7 cases, the court appoints a trustee to manage the firm's property, which is taken from the debtor and placed in the bankruptcy "estate."27 In Chapter 11 cases, the courts rarely appoint a trustee; the firm's management usually exercises the powers of the trustee. ${ }^{28}$ Although the Code places the debtor's property in the bankruptcy estate, the trustee is not required to manage all of those assets. She may "abandon," or return to the debtor, "any property of the estate that is burdensome ... [or] of inconsequential value." 28

The filing of the petition triggers an automatic stay, which halts most judicial proceedings that could reach the debtor's assets. ${ }^{30}$ An exception is made for certain government actions to enforce police and regulatory powers. ${ }^{31}$ Crucial to the purposes of bankruptcy law, the automatic stay prevents the inefficiency of individual creditor remedies; without the stay, creditors might dismember a firm that had more value if sold in larger pieces or as a going concern. ${ }^{32}$

With the automatic stay in place, the primary task of bankruptcy proceedings is the distribution of the debtor's assets to the creditors. ${ }^{33}$ The Code recognizes two broad classes of creditors, secured creditors and unsecured creditors; secured creditors generally have first rights to the debtor's assets. Non-bankruptcy law determines whether a creditor is secured or unsecured, although the Code recognizes as secured only those creditors who have perfected their liens pre-petition; the trustee may "avoid" any lien perfected post-petition, ${ }^{34}$ leaving the creditor unsecured. A creditor

${ }^{25}$ Id at $\S \S 301,303$.

${ }^{30}$ Id.

${ }^{27}$ Id at $\$ \S 704,541-42$.

28 Id at $\$ 1107(a)$. This Comment uses the word "trustee" to denote the person responsible for managing the estate.

${ }^{29}$ Id at $\S 554(\mathrm{a})$. There are some limitations on this power. See text at note 44 , note 92 .

so Id at $\$ 362$.

32 Id at $\S 362(\mathrm{~b})(5)$.

32 Thomas H. Jackson, The Logic and Limits of Bankruptcy Law 7-19, 151-52 (Harvard, 1986).

ss This presumes liquidation. Reorganization should not result in a significantly different distribution of assets, because each class of creditors is entitled to receive at least as much under the reorganization plan as it would have received under liquidation. 11 USC $\S 1129(\mathrm{a})(7)(\mathrm{A})(\mathrm{ii})$. Some special issues arising only in reorganization are discussed in Section III.B.

3. Id at $\S 544$. 
with a security interest in property worth less than the amount owed is considered to have a secured claim worth the value of her collateral and an unsecured claim for the remainder..$^{35}$

Certain unsecured claims arising after the filing of the petition merit special treatment as administrative expenses. ${ }^{36}$ Such claims are paid before other unsecured claims, although generally after secured claims. ${ }^{37}$ Administrative expense priority is reserved for the "actual, necessary costs and expenses of preserving the estate." ${ }^{38}$ The Code grants priority to these claims on the theory that those who provide goods and services to the estate will not do so without assurance of full repayment. And without the ability to purchase certain goods and services-for example, the management skill of a trustee, electricity for offices, or raw materials to keep factories going - the bankruptcy estate would be deprived of revenues that it could use to pay creditors.

The courts, however, have not restricted administrative priority to post-petition suppliers of goods and services. In Reading Co. $v$ Brown ${ }^{39}$ the Supreme Court gave administrative expense priority to a tort victim who was injured after the company filed for bankruptcy. Lower courts have extended the Reading holding beyond common law torts to most non-consensual liabilities, including liabilities arising from statutes. ${ }^{40}$

\section{Caselaw on CERCLA Reimbursement Claims in Bankruptcy}

The Supreme Court has decided two cases involving CERCLA in a bankruptcy setting. In Ohio $v$ Kovacs, ${ }^{41}$ the Court held that when the state had issued an injunction ordering an individual debtor to clean up and a court had appointed a receiver to manage the debtor's property, the injunction constituted a "claim" and was dischargeable in bankruptcy. ${ }^{42}$ In Midlantic National Bank $v$ New Jersey, ${ }^{43}$ the Court held that in cases involving imminent danger

ss 11 USC § 506(a).

se Id at $\S 503$.

37 Id at $\$ \S 507(a), 726$.

38 Id at $\S 503$.

391 US 471 (1968).

40 See, for example, In re Charlesbank Laundry, Inc., 755 F2d 200, 201-02 (1st Cir 1985) (fine for violation of injunction to enforce zoning ordinance); Long Chemical, 45 Bankr 278 (CERCLA reimbursement claim).

41469 US 274 (1985).

42 The discharge of a claim releases the debtor from any liability and terminates the creditor's rights with respect to the claim.

4s 474 US 494 (1986). See also note 92. 
the trustee could not abandon properties contaminated by hazardous wastes. Although the Code does not place any restrictions on the power to abandon property, the Court justified its result by looking to a tradition of judicially created exceptions to the abandonment power and by noting recent congressional activity indicating "repeated emphasis on [the] goal of protecting the environment against toxic pollution." 44

In neither Kovacs nor Midlantic did the Court address the priority of reimbursement claims, thus leaving the question to the lower courts. Lower courts have split on the issue of whether to grant administrative expense priority to CERCLA reimbursement claims. Neither side of the debate has provided sound arguments for its conclusion.

In the first case to address the issue, In re T. P. Long Chemical, Inc., ${ }^{45}$ the court held that CERCLA reimbursement claims were entitled to administrative expense priority. The key to the court's reasoning is the following passage:

Since the estate cannot [through abandonment] avoid the liability imposed by CERCLA, it follows that the cost incurred by the E.P.A. in discharging this liability is an actual necessary cost of preserving the estate entitled to administrative expense priority. The necessity of the expense cannot be questioned since the removal of the wastes was an obligation of the estate under CERCLA. ${ }^{46}$

Most courts have adopted Long Chemical's reasoning, some quoting this passage in full. ${ }^{47}$ Long Chemical and its successors essentially argue as follows:

1) Midlantic prohibits the trustee from abandoning contaminated property. ${ }^{48}$

2) If the trustee cannot abandon the property, she must comply with all applicable laws relating to the property. ${ }^{49}$

474 US at 505.

4s 45 Bankr 278.

16 Id at 286-87 (citation omitted).

47 See, for example, Wall Tube, 831 F2d at 123-24 (quoting in full); Stevens, 68 Bankr at 779 (quoting in full); Mowbray Engineering, 67 Bankr at 35 (relying heavily on Long Chemical).

48 See Long Chemical, 45 Bankr at 286; Stevens, 68 Bankr at 780; Wall Tube, 831 F2d at 121; Peerless Plating, 70 Bankr at 947; Chateaugay Corp., 112 Bankr at 525.

40 See Long Chemical, 45 Bankr at 286-87; Stevens, 68 Bankr at 781; Wall Tube, 831 F2d at 121; Peerless Plating, 70 Bankr at 948; Chateaugay Corp., 112 Bankr at 525. 
3) CERCLA is an applicable law, and CERCLA imposes an obligation to clean up the property. ${ }^{50}$

4) Cleanup, if performed by the trustee, would be an administrative expense, because any expenditure required by law is "necessary" under the Bankruptcy Code. ${ }^{51}$

5) If the trustee fails to perform her obligation and the EPA cleans up, the EPA should "step into the shoes" of the trustee. Thus, because cleanup, if performed by the trustee, would have received administrative expense status, the EPA's reimbursement claim should also receive at least that status; otherwise, the estate would benefit by the trustee's violation of the law. ${ }^{\mathbf{5 2}}$

This argument has a number of problems. Step 1 misreads the Supreme Court's decision in Midlantic. That case created only a narrow exception to the abandonment power, for cases involving "imminent and identifiable harm." In other cases, the trustee is free to abandon. ${ }^{53}$

Steps 2 and 4 ignore the fact that an insolvent firm, by definition, cannot fulfill all its legal obligations. Repayment of unsecured creditors is also an expenditure required by law. The question is how to fix the order in which obligations will be performed. The mere fact that environmental cleanup is an obligation does not indicate its priority. In some cases ${ }^{54}$ step 2 is supported by citation to 28 USC $\S 959(\mathrm{~b})$, which requires each trustee to "manage and operate the property in his possession ... according to the requirements of the valid laws of the State in which such property is situated." This citation is problematic for two reasons. First, by its terms it applies only to state laws, not federal laws like CERCLA. Second, as the Supreme Court noted in Reading, this provision "establishes only the principle of liability ... and does not decide . . . with what priority."

Step 3 misinterprets CERCLA. Unless the EPA issues an order or procures an injunction, the trustee does not violate CER-

\footnotetext{
${ }^{\text {so }}$ See Long Chemical, 45 Bankr at 287; Peerless Plating, 70 Bankr at 948. Some cases rely on state environmental law to supply the obligation to clean up. To the extent the state laws mandate cleanup, they are analogous to the EPA's power to compel cleanup through administrative orders and injunctions, and the arguments in Section IV would apply.

${ }^{81}$ See Long Chemical, 45 Bankr at 287; Peerless Plating, 70 Bankr at 948-49; Chateaugay Corp., 112 Bankr at 525.

${ }^{82}$ See Mowbray Engineering, 67 Bankr at 35; Stevens, 68 Bankr at 782; Wall Tube, 831 F2d at 124; Peerless Plating, 70 Bankr at 949.

${ }^{8 s}$ See note 92.

s4 Chateaugay Corp., 112 Bankr 513; Wall Tube, 831 F2d at 121; Stevens, 68 Bankr at 781.

${ }^{85} 391$ US at $477 \mathrm{n} 7$.
} 
CLA by failing to act. CERCLA imposes no affirmative obligation to clean up but merely provides mechanisms by which the EPA can recover some of its costs.

Step 5, while possibly correct in theory, lacks statutory or caselaw support. Although a bankruptcy court might use its equitable powers under $\S 105$ of the Code to recognize this approach, the conclusion fails because of the weaknesses in the previous elements of the argument.

Two courts have rejected Long Chemical's reasoning and treated CERCLA reimbursement claims as ordinary unsecured claims. The arguments of these cases, however, are also unsatisfying, because both courts erroneously assumed that Kovacs decided the priority question. ${ }^{56}$

\section{CeRCLA Reimbursement Claims as Ordinary UNSECURED ClaIMS}

The question of the priority of CERCLA reimbursement claims is most challenging when the release ${ }^{87}$ of the hazardous substances occurs pre-petition, but when cleanup does not occur until post-petition. ${ }^{88}$ This scenario will be assumed for the rest of the Comment.

At first it might seem that because CERCLA gives the EPA a lien, ${ }^{69}$ CERCLA reimbursement claims are secured claims. The lien, however, is perfected at the time of cleanup-post-petition-and is avoidable under the Bankruptcy Code. Lien avoidance renders the claim unsecured.

Because the EPA's claim is unsecured, the remaining issue is whether the EPA is entitled to administrative expense priority. This Section argues that reimbursement claims are not entitled to administrative expense priority. The argument draws support from an economic interpretation of the Supreme Court's decision in Reading, caselaw supporting the view that the claims arise pre-petition, and congressional intent.

36 Dant \& Russell, 853 F2d at 708; Southern Railway, 753 F2d at 142.

87 'The term 'release' means any spilling, leaking, pumping, pouring, emitting, emptying, discharging, injecting, escaping, leaching, dumping, or disposing into the environment. . . " 42 USC § 9601 (22).

ss Other scenarios are relatively uncontroversial. Where both release and cleanup are pre-petition, the reimbursement claim is a secured claim up to the value of the EPA's lien, and an ordinary unsecured claim for the rest. Where release is post-petition, the reimbursement claim is entitled to administrative expense priority.

s9 42 USC \& 9607(1). 


\section{A. Applying Reading to CERCLA Reimbursement Claims}

For unsecured claims, the key question is whether Reading elevates the claim to administrative expense status. In Reading, the Supreme Court granted administrative expense priority to a claim for property damage resulting from a post-petition fire. ${ }^{60}$ The statutory basis for this decision was weak. Under the Bankruptcy Code, administrative expenses are "the actual, necessary costs and expenses of preserving the estate." 61 Yet compensation for property damage does not preserve the estate, but depletes it. Therefore, instead of relying solely on the Code, the Court also gave several non-statutory justifications for its decision, including "fairness" and the desirability of encouraging firms to obtain insurance. ${ }^{62}$ Later courts have generally ignored these justifications, even when adopting Reading's holding.

An economic justification for the Reading result might also be given. The unsecured creditors elect the trustee, who generally acts in their interests. ${ }^{63}$ Administrative expense priority is necessary to force the trustee to internalize the social costs of the continued operation of the estate's assets. If tort claims were treated like the claims of other unsecured creditors, tort victims would rarely receive full compensation. But if the estate had to pay for only a fraction of the injuries it caused, the trustee would not have the full incentive to take adequate precautions.

Critics of this economic justification for Reading argue that the failure to internalize adequately the social costs of accidents is a consequence of non-bankruptcy law, because insolvent firms can reorganize or dissolve under state law, where there is no special category of administrative expenses. ${ }^{64}$ Correcting inadequate internalization only in bankruptcy merely encourages forum shopping. Yet this critique ignores the essential difference between bankruptcy and state-law proceedings. The automatic stay, available only under bankruptcy law, aggravates the insolvent firm's failure to internalize the costs of accidents. An insolvent firm not in bankruptcy has strong incentives to dissolve or restructure quickly, in

391 US at 485 .

o1 11 USC \& 503(b)(1)(A).

391 US at $477,483$.

6s 11 USC § 702.

6 Thomas H. Jackson, Of Liquidation, Continuation, and Delay: An Analysis of Bankruptcy Policy and Nonbankruptcy Rules, 60 Am Bankr L J 399, 423-27 (1986); Douglas G. Baird and Thomas H. Jackson, Cases, Problems, and Materials on Bankruptcy 707 08 (Little, Brown, 2d ed 1990). 
order to prevent creditors from using their individual remedies to dismember the firm. But the bankrutpcy stay blocks those remedies, and it is not uncommon for firms to remain in bankruptcy for years, during which many serious torts may be committed. ${ }^{65}$ Bankruptcy allows the trustee to manage assets that outside of bankruptcy would have been sold to solvent entities with adequate incentives to internalize social costs. As the Court stated in Reading, a post-petition tort victim has "an insolvent business thrust upon it by operation of law."66

This economic interpretation of Reading suggests limiting administrative expense priority to claims resulting from the trustee's management of the firm's assets. Administrative expense priority is needed for those claims to correct the inadequate internalization that bankruptcy law creates by prolonging the life of insolvent firms. However, for claims that would have existed even if the trustee had not taken control, such as CERCLA reimbursement for pre-petition release of hazardous waste, bankruptcy law has not aggravated the problem of inadequate internalization. There is, therefore, no reason to give such claims special priority.

\section{B. CERCLA Reimbursement Claims as Pre-petition Claims}

Although not employed by the Court in Reading, a common approach to determining whether a claim is entitled to administrative expense priority asks when the claim arose. ${ }^{67}$ Those claims arising post-petition are granted administrative expense status, while those arising pre-petition are treated as ordinary unsecured claims. ${ }^{68}$ Because CERCLA reimbursement claims are best viewed as arising pre-petition, this analysis supports treating these claims as ordinary unsecured claims.

\footnotetext{
es Jackson recognizes this problem, but suggests "second generation" responses to ensure that bankruptcy delay is minimized (for instance, time limits on promulgation of plans). Jackson, $60 \mathrm{Am}$ Bankr L J at $427 \mathrm{n} 81$ (cited in note 64). Until Congress enacts such responses into law, however, Reading seems a rational approach to the problem.

391 US at 478.

${ }^{67}$ In re Alchar Hardware Co., Inc., 759 F2d 867 (11th Cir 1985); In re Charter, 52 Bankr 267 (Bankr M D Fla 1985).

os While Reading itself does not analyze administrative expense priority in terms of when the claim arose, such analysis is helpful because it links the priority question to related questions involving the automatic stay and discharge provisions, which explicitly distinguish between claims arising before and after a given time. 11 USC § 362(a)(1) (staying actions "to recover a claim ... that arose before the commencement of the case"); id at § 727(b) (discharging an individual debtor "from all debts that arose before the date of the order for relief"); id at $\$ 1141$ (d)(1)(A) (discharging a corporate debtor "from any debt that arose before the date of such confirmation").
} 
1. Caselaw treatment of the EPA's claim as a pre-petition claim.

Caselaw supports the view that CERCLA reimbursement claims should be considered pre-petition claims. This approach is consistent with that used by many courts in determining when personal injury claims arise for purposes of the discharge and automatic stay provisions. ${ }^{69}$ The leading case involved a dental patient who did not realize that his treatment was negligent until after his dentist had filed for bankruptcy. ${ }^{70}$ The court held that the claim arose at the time of the negligent treatment, not when the negligence became apparent. At the time of the negligent treatment, the patient had a contingent claim, that is, a right to payment contingent on the later manifestation of injury. Because this contingent claim arose before the dentist filed for bankruptcy, the claim was considered pre-petition.

Similarly, the EPA's reimbursement claim arises pre-petition, because the EPA acquires a contingent claim at the time hazardous substances are released into the environment. This expansive use of the term "claim" reflects the meaning of that term in the Bankruptcy Code. The Code defines "claim" to include any "right to payment, whether or not such right is reduced to judgment, liquidated, unliquidated, fixed, contingent, matured [or] unmatured."

This analysis also comports with a recent judicial interpretation of when CERCLA reimbursement claims arise for the purposes of discharge. In In re Chateaugay Corp., the court held that if the release was pre-petition, the resulting CERCLA reimbursement claim arose pre-petition. ${ }^{\mathbf{2}}$

Finally, In re Yanks ${ }^{73}$ provides additional support for this approach. The debtor operated a restaurant that was severely damaged by fire. A year after the fire, the debtor filed a bankruptcy petition. Several months later, an insurance company paid various

68 In re Edge, 60 Bankr 690 (Bankr M D Tenn 1986); see also Grady v A.H. Robins Co., 839 F2d 198, 202-03 (4th Cir 1988). A different approach was taken in In re Frenville Co., 744 F2d 332 (3d Cir 1984).

70 Edge, 60 Bankr 690 .

2111 USC $\S 101(4)(\mathrm{A})$. The legislative history of the Code indicates that by adopting the "broadest possible definition" of "claim," the Code seeks to treat all "legal obligations of the debtor, no matter how remote or contingent" in the bankruptcy case. Bankruptcy Law Revision, HR Rep No 95-595, 95th Cong, 1st Sess 309 (1977); Bankruptcy Reform Act of 1978, S Rep No 95-989, 95th Cong, 2d Sess 21 (1978).

72112 Bankr at 520-24.

73 49 Bankr 56 (Bankr S D Fla 1985). 
parties' claims for property damaged in the fire. Still later, it was determined that the debtor had set the fire and was therefore required to repay the insurance company. The insurance company requested administrative priority for its reimbursement claim against the debtor, arguing that its claim did not arise until it paid out money to those injured. The court, however, held that the claim arose at the time of the fire; the claim was therefore an ordinary unsecured claim. The EPA's position is very close to that of the insurer; both argue that their claims arose when they paid out money. This Comment and the court in Yanks, however, reject that position, arguing instead that the claims arose at the time the debtor committed the bad act-setting the fire or releasing the hazardous substances.

2. Critique of the argument that the EPA's claim arises postpetition.

The principal counterargument to the above analysis is that the trustee's failure to clean up the property, not the original release of toxic substances, gives rise to the EPA's claim. ${ }^{74}$ Because this failure continues post-petition, one could argue that the claim arises post-petition and is thus entitled to administrative expense priority. Under this view, imposition of liability is seen as necessary to induce the trustee to clean up the property.

This argument is problematic. First, granting administrative expense priority would induce the trustee to clean up only if the condition of the property is deteriorating. If the condition of the polluted property is stable, the cost of cleanup now is basically the same as the cost of reimbursing for cleanup later; the firm loses nothing by waiting. Granting administrative expense priority will induce the firm to act only when the cost of cleanup is rising. ${ }^{75}$ Thus, it might make sense to impose liability when the condition of the property is deteriorating. For a court to decide whether there is deterioration, however, may be difficult, requiring extended hearings and expert testimony. Of course, one could avoid this determination by granting administrative expense priority in all cases, but this overly broad solution would recognize administrative expense priority in a large number of cases where the priority in no way induces cleanup.

\footnotetext{
74 This argument is suggested, but not developed, in Wall Tube, 831 F2d at 122.

${ }^{76}$ In fact, the cost of cleanup would have to rise at a rate greater than the interest rate the trustee could receive by simply investing the money.
} 
Second, even if liability were restricted to those cases where the property continues to deteriorate, much of the reimbursement claim still will be essentially pre-petition. Suppose at petition the cost of cleanup was $\$ 20$ million, but the condition of the property deteriorated so that by the time the EPA cleaned up the property, the cost had risen to $\$ 25$ million. The firm's post-petition failure to act added $\$ 5$ million to the cost of cleanup. However, to induce cleanup (the premise of this counterargument), a court will have to give administrative expense priority for the entire $\$ 25$ million. Thus, $80 \%$ of the payment would be for pre-petition damage, an unprecedented extension of Reading's construction of administrative expense priority.

Third, granting administrative expense priority is simply not necessary to induce cleanup of deteriorating property. There are two classes of cases to consider: one, where the cost of cleanup is less than the market value of the land after cleanup, and another where it is greater.

If the cost of cleanup is less than the post-cleanup market price of the land, the trustee will sell the property. The buyer, however, will be liable under CERCLA and will therefore discount the price by the anticipated cost of cleanup. ${ }^{76}$ But if the buyer subtracts the anticipated cost of cleanup from the price, the trustee will have an incentive to clean up. For example, if the post-cleanup market price of the property is $\$ 20$ million, the cost of cleanup at petition is $\$ 7$ million, and the cost of cleanup at the time of sale is $\$ 10$ million, the trustee will clean up the property at the time of the petition because the estate will then net $\$ 13$ million; by waiting, the trustee will net only $\$ 10$ million. The trustee thus has an incentive to clean up the land, even if administrative priority is not given to the reimbursement claim. ${ }^{77}$

The difficulty with the above scenario is that the trustee might anticipate that the EPA will intervene before the property is sold, and thus-because the claim would be treated as an ordinary unsecured claim-that the estate will have to pay for only a fraction of the costs of cleanup. This possibility reduces the incentive for

\footnotetext{
${ }^{76}$ See David Carlson, Successor Liability in Bankruptcy: Some Unifying Themes of Intertemporal Creditor Priorities Created by Running Covenants, Products Liability, and Toxic Waste Cleanup, 50 L \& Contemp Probs 119, 120 (1987).

${ }_{77}$ The trustee would probably need the court's permission to spend money for the cleanup. This would require granting administrative expense priority. There is a strong case, however, for granting administrative expense priority here. Spending money in this case benefits the estate in the long run by ensuring a higher price for the property and is thus an "actual, necessary cost of preserving the estate." 11 USC $\S 503(\mathrm{~b})(1)(A)$.
} 
the firm in bankruptcy to clean up on its own. But prudent EPA decisionmaking should avoid this result. If the EPA calculates that it is in the estate's best interest for the trustee to clean up the property, it should refuse to act unless the court grants it priority. Because the EPA can wait until the property is sold and then clean up and get full reimbursement, it loses nothing by delay. As long as there is no emergency, the EPA's delay would not be improper. In addition, the EPA might clean up before the property is sold, but sue after the sale. In that case, the EPA could both abate the danger and collect full reimbursement.

If the cost of cleanup is greater than the post-cleanup market price, the firm will be unable to sell the property. In this case the firm will abandon the property. ${ }^{78}$ While abandonment does not affect the liability the estate already incurred by virtue of the firm's pre-petition ownership, the fact that the property will not be sold removes the incentive for the trustee to clean up. ${ }^{79}$ In this situation administrative expense priority-or an even higher priority-may seem necessary to prevent the property from deteriorating and possibly endangering human health. In fact, however, administrative expense priority is not necessary; there already exists a party with the capability and the motive to clean up: the EPA. Once the property is abandoned, the EPA will eventually pay for the increased cost of cleanup. It should get some reimbursement from the estate, and it should recover the post-cleanup sale price of the property.$^{80}$ But it is still likely to bear most of the cost of delay and thus has a large incentive to clean up.

At first glance it seems unsatisfactory to resolve this problem by simply saying "let the government take care of it." It would seem that this logic undermines Reading entirely, because the government can always take precautions for the trustee or pay the trustee to take precautions. Yet CERCLA is a special case. The government not only has the ability to intervene, but CERCLA gives it a direct financial incentive to do so: if it does not it will pay more later.

\footnotetext{
78 For a more complete discussion of abandonment, see text at notes 91-99.

70 Some courts have held that abandonment acts retroactively to divest the estate of the property at the time of the bankruptcy petition, and thus puts the estate in the same position as if it had never owned the property. Mason $v$ Commissioner of the IRS, 646 F2d 1309, 1310 (9th Cir 1980); Bryson v Bank of New York, 584 F Supp 1306, 1316 (S D NY 1984); In re Flamand, 78 Bankr 644, 645 (Bankr D RI 1987). If this fiction were accepted, the difficulty would disappear. If the estate never owned the property, it can hardly incur liability on account of failure to clean it up.

${ }^{80}$ See text at notes $91-99$.
} 
A final objection to the argument that the EPA's claim arises only with the trustee's failure to clean the site is that granting administrative expense status because of the deterioration of the property treats environmental damage more favorably than injury to people. ${ }^{81}$ Many human conditions, like broken bones or cancer, also deteriorate if not promptly treated, yet medical care does not by that fact become an administrative expense. Instead, the patient must herself seek treatment. After treatment, the patient, or her insurer, can petition for reimbursement. If the event giving rise to the injury occurred pre-petition, that claim will be treated as an ordinary unsecured claim, resulting in less than full reimbursement. If the government, through Medicare or Medicaid, is her insurer, it will bear the loss.

A CERCLA reimbursement claim by the EPA is analogous to a tort claim by a victim insured by Medicare. The condition of the contaminated property, like that of the cancer patient, will deteriorate if untreated. The EPA, like the cancer patient, must seek to remedy the condition on its own. ${ }^{82}$ The cost of the remedy-cleanup or medical treatment-will be borne by a government insurance fund, the Superfund or the Medicare Trust Fund. After the remedy, both can petition for reimbursement, and both will be treated as ordinary unsecured creditors.

\section{CERCLA Reimbursement Claims and Congressional Intent}

Treating the EPA's claim as an ordinary unsecured claim is also consistent with congressional intent as expressed in the 1986 amendments to CERCLA and in the Bankruptcy Code. In 1986, Congress gave the EPA a lien arising at the time of cleanup but rejected a proposal to give the EPA a lien arising at the time of the release. ${ }^{83}$ Such a lien would not have been avoidable, because it would have arisen pre-petition, ensuring payment in full of reimbursement claims. ${ }^{84}$ By rejecting such a lien, Congress implied that EPA claims for reimbursement are not that different from other

81 There are a few groups that advocate such a preference. See the description of Earth First! in Gregg Easterbrook, Everything You Know About the Environment is Wrong: $A$ Liberal Skeptic's Guide to Earth, New Republic 14, 18 (Apr 30, 1990).

82 The EPA's ability to order the trustee to remedy the condition of polluted property is discussed in Section IV.

${ }^{8}$ Laurel E. Lockett, Environmental Liability Enforcement and the Bankruptcy Act of 1978: A Study of H.R. 2767, the "Superlien" Provision, 19 Real Prop Probate \& Trust J 859 (1984).

8. See Richard L. Epling, Environmental Liens in Bankruptcy, 44 Bus Law 85, 92 (1988); Lockett, 19 Real Prop Probate \& Trust J at 883 (cited in note 83). 
non-governmental claims and should not be given special treatment.

One might even argue that Congress expressed a desire for EPA reimbursement claims to be treated less favorably than similar private claims. Outside of bankruptcy, a worker who repairs a piece of property receives a mechanic's lien on that property, which is superior even to preexisting liens. ${ }^{85}$ Thus, the worker is placed in a better position even than prior secured creditors. Although in cleaning up property, the EPA is much like a worker who repairs a piece of machinery, Congress gave the EPA a lien junior to preexisting liens.

In addition, treating the EPA's claims as ordinary unsecured claims reflects congressional intent as expressed in the Bankruptcy Code. In enacting the Code, Congress did not give the government, in its capacity as creditor rather than regulator, special priority. ${ }^{86}$ The legislative history on the automatic stay illuminates this point:

[The Code] makes clear that the exception [to the automatic stay] ... does not extend to permit enforcement of a money judgment. Since the assets of the debtor are in the possession and control of the bankruptcy court, and since they constitute a fund out of which all creditors are entitled to share, enforcement by a governmental unit of a money judgment would give it preferential treatment to the detriment of all other creditors. ${ }^{87}$

The drafters of the Code did not want to give the government preferential treatment when it merely collects money, as the EPA does when seeking reimbursement for expenses already incurred.

\section{Securing Other Private Funds for Cleanup}

Even though reimbursement claims are properly treated as ordinary unsecured claims, the EPA should be able to recover additional funds for cleanup of the property. This Section argues that CERCLA's liability provisions enable the EPA to recover its cleanup costs from subsequent purchasers in liquidations (under Chapter 7) or from the firm itself after reorganizations involving retention of the property (under Chapter 11). In addition, CERCLA's lien provisions should enable the EPA to recover from the post-cleanup proceeds from the sale of the property, if it is aban-

os UCC § 9-310 (ALI 1972).

so There are, however, some exceptions. See 11 USC $\$ 507(a)(7)$.

${ }^{67}$ HR Rep No 95-595 at 343 (cited in note 71). 
doned (under Chapter 7) or excluded from the reorganization plan (under Chapter 11). Under both chapters, two classes of cases must be considered: where the cost of cleanup is less than the market value of the land after cleanup, and where the cost is greater.

\section{A. Liquidations}

If the cost of cleanup is less than the post-cleanup market price of the land, the trustee in a Chapter 7 case will sell the property. CERCLA, however, holds the buyer liable. ${ }^{88}$ Thus, if the EPA waits, it can gain full reimbursement from the new owner. As long as there is no emergency, there is nothing improper about the EPA's delay. ${ }^{89}$ It might even be possible for the EPA to clean the site before the property is sold and sue for reimbursement after the property is sold. The plain language of CERCLA supports imposing liability on the new owner, even if the cleanup occurred before she acquires the property. CERCLA provides that "the owner or operator of a vessel or facility ... shall be liable for all costs of removal or remedial action." "90 Liability is not limited to the owner at the time of cleanup. No cases, however, have tested the validity of this reading.

If the cost of cleanup is greater than the post-cleanup market price; the firm will not be able to sell the property. In this case the firm will probably try to abandon the property. ${ }^{\text {91 }}$ The Supreme Court's decision in Midlantic placed some restrictions on the abandonment power, ${ }^{92}$ but courts have allowed abandonment as long as

s8 Current owners are liable unless they can prove a defense. 42 USC $\$ 9607$ (a)(1), (b). There is a defense for damage caused by "an act or omission of a third party," but the third party must not be in a "contractual relationship" with the current owner. Id at $\S 9607(b)(3)$. CERCLA defines "contractual relationship" to include "land contracts, deeds or other instruments transferring title or possession." Id at $\S 101(35)(\mathrm{A})$.

${ }^{80}$ If there is an emergency and the cost of the response is less than the post-cleanup value of the property, it might be appropriate to give administrative expense priority. Cleanup in this case confers a benefit on the estate and could reasonably qualify as an actual, necessary cost of preserving the estate. 11 USC $\$ 503(\mathrm{~b})(1)(\mathrm{A})$.

so 42 USC $\S 9607(\mathrm{a})$.

91 There are some cases, however, in which the trustee might decide to clean up anyway. Consider the following model:

Let $p$ be the percentage of unsecured claims that are paid in the final distribution.

Let $\mathrm{V}$ be the post-cleanup market value of the property.

Let $\mathrm{C}$ be the cost of cleanup.

If the trustee abandons, the estate is liable for $\mathrm{pC}$.

If the trustee cleans up, it pays $\mathrm{C}$, but gains $\mathrm{V}$.

Thus, if $\mathrm{C}-\mathrm{V}$ is less than $\mathrm{pC}$, the trustee might clean up. Alternatively, the trustee might pay someone up to $\mathrm{C}-\mathrm{V}$ to take title to the property with an agreement to indemnify the estate for any post-conveyance CERCLA liability.

92474 US at $507 \mathrm{n} 9$ ("The exception to the abandonment power . . . is a narrow one 
there is no imminent danger..$^{93}$ Abandonment, however, does not affect the liability incurred by virtue of the pre-petition release; the EPA will still be able to assert its reimbursement claim against the estate.

In addition, the EPA can receive the proceeds of the postcleanup sale of the property. ${ }^{94}$ How this is accomplished depends

... . to protect the public health or safety from imminent and identifiable harm."). Nearly all courts have followed this language and have limited the abandonment power only in narrow circumstances. See, for example, In re Smith-Douglass, 856 F2d 12, 16 (4th Cir 1988); In re FCX, 96 Bankr 49, 54-55 (Bankr E D NC 1989); In re Purco, Inc., 76 Bankr 523, 532-33 (Bankr W D Penn 1987); In re Pierce Coal and Construction, Inc., 65 Bankr 521, 528, 531 (Bankr D Mass 1986); In re Franklin Signal Corp., 65 Bankr 268, 272 (Bankr D Minn 1986); and In re Oklahoma Refining Co, 63 Bankr 562, 565 (Bankr W D Okla 1986).

Only one court has forbidden abandonment, but it authorized "conveyance of the possessory interest in the site to the EPA," which achieves the same result. In re Milbar Blvd., 91 Bankr 213, 219 (Bankr E D NY 1988). The only other cases which have suggested that abandonment is forbidden are cases which discuss abandonment in analyzing the priority question, not cases involving a debtor who is attempting to abandon the property. See cases cited in note 48 . In addition, disallowing abandonment makes sense only if, contrary to the conclusions of Section IV, administrative orders and injunctions are exempted from the automatic stay. Otherwise, the trustee could just wait until the close of the bankruptcy case, at which time the property would be abandoned automatically. 11 USC $\$ 554$ (c). Any attempt to block abandonment at that time would be futile, because the estate would not longer have any assets with which to clean up.

93 See, for example, Franklin Signal Corp., 63 Bankr at 272 ("The trustee only needs to take adequate precautionary measures to ensure that there is no imminent danger to the public as a result of abandonment."). For additional cases see note 92.

What happens if an imminent danger exists, and the trustee is not allowed to abandon? A full answer to this question is outside the scope of this Comment. A brief discussion, however, may be helpful. CERCLA does not require cleanup, and even when state laws do, the priority question remains. See text at notes 54-55. The trustee is faced with two alternatives. First, she might take remedial measures short of full cleanup to reduce the imminent danger and then abandon. The Court in Midlantic implied that abandonment would not have been prohibited if the trustee had taken "relatively minor steps to reduce imminent danger, such as security fencing, drainage and diking repairs. . ." 474 US at 758 n 3 . Second, she might simply do nothing. If there is an imminent danger, the EPA has a strong incentive to cleanup, lest the costs of cleanup-which it will probably bear-go up. If the EPA does clean up, it can sue for reimbursement under CERCLA and be repaid as an ordinary unsecured creditor. If it does not, the property is automatically abandoned to the debtor at the closing of the bankruptcy case. 11 USC \& 554(c). Any attempt to prevent this abandonment would be futile; by the close of the bankruptcy case, all valuable assets will have been sold and the proceeds already distributed.

of This right may be frustrated, however, if there is a creditor with a prior lien on the property. CERCLA's lien provision is structured to preserve liens that are perfected prior to the CERCLA claim. 42 USC \& 9607(l). The EPA may be able to negotiate with the lien holders to release their liens. The EPA is in a strong position, because the other liens are worthless unless the EPA cleans up. That secured creditors can be persuaded to relinquish parts of the liens has been demonstrated in the Bofors negotiation. Stewart H. Freeman and Stanley F. Pruss, Obtaining a Covenant Not to Sue from the Government-Acquisition of a Contaminated Site by An Innocent Purchaser: The Bofors, Michigan Site, A New Beginning after SARA, in Randy M. Mott, ed, Hazardous Waste Litigation After RCRA and CERCLA Amendments 1987 429, 434, 442 (PLI, 1987) (secured creditors with over $\$ 40$ mil- 
on the fate of the property after abandonment. The commencement of the bankruptcy case removes the property from the debtor and places it in the bankruptcy estate under the trustee's management. Abandonment revests the debtor with the property. ${ }^{98}$ If the EPA cleans up the property before the closing of the bankruptcy case, it may have difficulty attaching its lien and recovering the value of the property because of the automatic stay. It should, however, be able to secure relief from the stay. ${ }^{96}$ The purpose of the stay is to prevent any one creditor from achieving undue advantage over other creditors. However, allowing the EPA to attach its lien, sell the property, ${ }^{97}$ and retain the proceeds does not give the EPA any undue advantage, because the property is worthless without its actions. Alternatively, the EPA can simply wait until after the closing of the bankruptcy case, when the stay no longer operates. ${ }^{98}$ The EPA's power to condemn property may also assist it in gaining the post-cleanup proceeds of the sale of the property. ${ }^{99}$

\section{B. Reorganizations}

The results described above will be substantially the same if the debtor files for reorganization under Chapter 11. If the property is worth more than the cost of cleanup, the new owner of the polluted property-the reorganized firm-should be liable. The EPA will thus be paid in full. If the property is worth less than the cost of cleanup, the court should permit the reorganized firm to refuse to take ownership of the polluted property. EPA recovery will thus be limited to its unsecured claim in bankruptcy and the proceeds of the post-cleanup sale of the property.

1. The theory of reorganization and the corporate discharge.

In Chapter 11, the creditors bargain over the financial restructuring of the firm. In a successful reorganization, the creditors reach agreement on a reorganization plan, which is then confirmed

lion in claims accepted a settlement in which they received under $\$ 8$ million while environmental authorities received $\$ 15$ million).

${ }^{86}$ Mason, 646 F2d at 1310; Bryson, 584 F Supp at 1316; Flamand, 78 Bankr at 645.

${ }^{96} 11$ USC § 362(d).

87 Of course, sale of the property will only be possible if the EPA promises not to sue later for reimbursement or at least agrees to limit the purchaser's liability. See Freeman and Pruss, Obtaining a Covenant Not to Sue from the Government, in Mott, ed, Hazardous Waste Litigation at 429, 439 (cited in note 94).

${ }^{98} 11$ USC \& 362(c)(2).

" 89 USC $\$ 9605(\mathrm{j})$. 
by the bankruptcy court. ${ }^{100}$ Reorganization is best viewed as a sale of the debtor's assets to its former creditors. ${ }^{101}$ The principal differences between Chapter 7 and Chapter 11 are the identity of the buyers and the means of payment. In Chapter 7 anyone can buy, and the buyers pay with cash, whereas in Chapter 11, the pre-petition creditors purchase the firm by the cancellation ("discharge") of their claims. Although firms in Chapter 7 are usually liquidated and firms in Chapter 11 are usually reorganized as going concerns, this need not be so. Trustees can sell firms in Chapter 7 as going concerns, and a Chapter 11 reorganization may involve a liquidation. ${ }^{102}$

The Bankruptcy Code is generally neutral between Chapter 7 and Chapter 11, and between liquidation and preserving the firm as a going concern. ${ }^{103} \mathrm{~A}$ firm should choose between the two chapters on the basis of whether the firm's assets will be most productive under the collective ownership of the pre-petition creditors or under the ownership of others. Similarly, it should choose between liquidation and reorganization as a going concern on the basis of whether the firm's assets are most productive when used together under a single owner or under diverse ownership.

The Code achieves this neutrality in part through the Chapter 11 discharge. ${ }^{104}$ The discharge releases the reorganized firm from liability for most debts arising before confirmation of the reorganization plan. At first blush, the discharge might seem to favor Chapter 11 over Chapter 7, because corporate debtors in Chapter 7 do not receive a discharge. But the sale of a Chapter 7 debtor's assets gives the debtor a de facto discharge. After the debtor's assets are sold and the proceeds distributed to its creditors, there is no gain in suing the now-penniless debtor, which will probably dissolve under state law. In Chapter 11, however, the corporate entity continues after the termination of the bankruptcy proceedings and will usually have substantial assets. The firm must thus be given a discharge to offset the Chapter 7 debtor's de facto discharge.

The discharge also comports with the theory that Chapter 11 is a sale of the corporation's assets to its pre-petition creditors. If

10011 USC \& 1129.

101 Baird and Jackson, Cases, Problems, and Materials on Bankruptcy at 726 (cited in note 64); Lucian Arye Bebchuk, A New Approach to Corporate Reorganizations, 101 Harv L Rev 775, 776 (1988).

${ }_{102}$ See Douglas G. Baird, The Uneasy Case for Corporate Reorganization, 15 J Legal Stud 127, 139 (1986).

${ }^{203}$ Jackson, The Logic and Limits of Bankruptcy Law at 212-13 (cited in note 32).

10411 USC § 1141(d). 
the firm's assets had been sold under Chapter 7, the new owners would not be liable for ordinary pre-petition debts. Similarly, the reorganized firm should not be liable.

\section{Application to CERCLA Claims.}

a) Cleanup cost less than market value after cleanup. Where cleanup costs are less than the post-cleanup value of the property, the reorganized firm is likely to keep the property. Initially, it might seem that the Chapter 11 discharge provisions would bar suit for CERCLA reimbursement against the reorganized entity when the suit arises out of pre-petition releases. If the release was pre-petition, the reimbursement claim is certainly preconfirmation and thus dischargeable. ${ }^{105}$

To preserve neutrality between Chapters 7 and 11 , however, the reorganized entity must be liable. If the firm's assets had been sold in a Chapter 7 proceeding, the new owners would be liable parties under CERCLA. ${ }^{106}$ Unless the reorganized entity under Chapter 11 is treated the same as the new owners under Chapter 7, the Code will create inefficient incentives favoring Chapter 11 over Chapter 7. A firm that has more value (excluding the cost of cleanup) in liquidation than reorganization may nevertheless reorganize in order to avoid liability through discharge. Only by preserving symmetry in liability will the proper neutrality between Chapter 7 and Chapter 11 be maintained.

The best way to preserve this symmetry is to recognize that CERCLA imposes new liability each time the land is sold. Admittedly, the plain language of $\S 1141$ mandates discharge of pre-petition debts, but permitting CERCLA liability after reorganization is more consistent with the theory and structure of the Code. If the land is sold outside of Chapter 11, new liability arises with respect to the buyer; the EPA has a contingent claim against her that did not exist before the sale. Just as new liability arises on sale outside of Chapter 11, so too in Chapter 11, new liability should arise with respect to the new owner, the reorganized entity. Under this view, new liability can be imposed despite the discharge. The pre-confirmation claim is technically discharged, but a new liability arises by virtue of the reorganized entity's "purchase" of the polluted land.

${ }^{105} 11$ USC $\S 1141$ (d). There are a few narrow exceptions.

${ }^{108}$ See text at notes $88-90$. 
Unfortunately, the one court that has examined this question did not take into account the fact that CERCLA reimbursement liability arises anew upon sale. Instead, the court treated post-reorganization reimbursement claims as simple pre-petition claims and denied liability on the theory that the claims were discharged. ${ }^{107}$

b) Cleanup cost exceeds market value after cleanup. If cleanup costs exceed the post-cleanup value of the property, the reorganized firm will want to avoid ownership of the property. Once again, however, the Code's provisions seem to create an asymmetry between Chapter 7 and Chapter 11. In Chapter 7, the trustee would abandon the property. But abandonment may not have the desired effect in Chapter 11. Abandonment takes the property out of the bankruptcy estate and revests it in the debtor, the pre-petition firm. Confirmation of the reorganization plan revivifies the old firm by transferring to it the assets remaining in the estate. ${ }^{108}$ Thus, the reorganized firm will end up owning the abandoned property. Under the assumption that reorganization should be viewed as a sale of assets, new CERCLA liability will arise with respect to the reorganized firm, in spite of abandonment. This would create a preference for Chapter 7 over Chapter 11. In Chapter 7 the purchaser of the assets could choose not to acquire the contaminated property and thereby avoid CERCLA liability, while under Chapter 11 the reorganized firm could not avoid acquiring the contaminated property.

The Bankruptcy Code contains a means to correct this asymmetry. If instead of abandoning the property, the debtor-in-posses$\operatorname{sion}^{109}$ holds on to it, the reorganization plan could provide that the contaminated property not revest in the firm. The Code states that, "[e]xcept as otherwise provided in the plan ... the confirmation of a plan vests all of the property of the estate in the debtor."110 By providing that the property not vest in the reorganized firm, the reorganization plan can thus exclude the property from the reorganized firm.

The fate of such excluded property is somewhat uncertain. The property may be ownerless, it may escheat to the state, or it may devolve to the pre-petition shareholders. But in any case, CERCLA will not hold the reorganized firm liable, and neutrality

\footnotetext{
${ }^{10 z}$ Chateaugay Corp., 112 Bankr at 524.

10811 USC \& 1141(b).

108 When a trustee is not appointed, the firm's managers run the bankruptcy estate and are called the debtors-in-possession. 11 USC § 1107.

${ }^{110}$ Id at $\S 1141$ (b) (emphasis added).
} 
between Chapter 7 and Chapter 11 will have been restored. As with abandoned property in Chapter 7, the EPA can recover the post-cleanup sale price of the property through CERCLA's lien and condemnation provisions.

Although the Code seems to allow a reorganization plan to exclude the contaminated property from the reorganized firm, this strategy remains untested. If it fails, a court might still use its equitable powers ${ }^{111}$ to reach the same result by allowing the reorganized firm not to assume ownership of the polluted property, or by vesting the firm with ownership but discharging any post-confirmation reimbursement claim in excess of the post-cleanup value of the contaminated property.

Even if these stratagems fail, the result is not disastrous. At worst, reorganized firms would be forced to assume full liability, resulting in a preference for Chapter 7. Because a firm can be sold as a going concern even under Chapter 7 , discouraging reorganization need not lead to an inefficient allocation of resources. In addition, discouraging reorganization, with its questionable theoretical justification, is not as serious as discouraging the use of Chapter 7. ${ }^{112}$ Moreover, any adverse effects can be mitigated through negotiation with the EPA. The EPA gains nothing by forcing liquidation, while other creditors may gain much by reorganization. There is therefore room for bargaining. The EPA might agree to a release of liability in return for a larger payment than it would have received in liquidation. ${ }^{113}$

\section{The EPA's Power to Issue Orders and Secure INJUNCTIONS}

This Comment has assumed that the EPA would clean up the contaminated property and then petition the owner for reimbursement. CERCLA, however, gives the EPA another method to force the owner to pay for the cleanup. In cases where "there may be an imminent and substantial endangerment," the EPA can issue administrative orders or secure injunctions requiring the owner to abate the danger. ${ }^{114}$ Although this provision was probably intended

${ }^{111}$ Id at $\$ 105(a)$.

112 See Baird, 15 J Legal Stud at 139 (cited in note 102).

${ }^{113}$ Such negotiations have been successfully conducted. See Freeman and Pruss, $O b$ taining a Covenant Not to Sue from the Government, in Mott, ed, Hazardous Waste Litigation at 429,432 (cited in note 94 ).

${ }_{114} 42$ USC \& 9606(a). See Anderson, Mandelker, and Tarlock, Environmental Protection at 660-62 (cited in note 19). 
for use only in emergency situations, the EPA has begun to use orders and injunctions as routine methods for ensuring that private parties pay most of the cleanup costs. The courts have facilitated the agency's efforts through liberal interpretion of the "imminent and substantial endangerment" requirement. ${ }^{115}$

Allowing enforcement of CERCLA orders and injunctions, however, covertly raises the priority of CERCLA reimbursement claims. ${ }^{116}$ If enforcement of CERCLA orders and injunctions were permitted, the trustee would have to spend money to comply. That money would come from the funds that otherwise would go to the unsecured creditors, effectively giving environmental cleanup a priority higher than that of the ordinary unsecured creditor. ${ }^{117}$

For this reason, the automatic stay should bar enforcement of CERCLA orders and injunctions. ${ }^{118}$ Certain government actions are exempted from the stay, including "the enforcement of a judgment, other than a money judgment, obtained in an action or proceeding to enforce such governmental unit's police or regulatory power."118 But CERCLA orders and injunctions properly fall outside this exception, as indicated by the legislative history of the Code. ${ }^{120}$ The House Report explains that the enforcement of

216 See text at notes 19-22.

116 The arguments in this section apply only to injunctions relating to pre-petition releases. If the release occurred post-petition, exemption from the stay would be appropriate, just as administrative expense status would be appropriate for reimbursement claims. See note 58 .

117 See Baird and Jackson, Cases, Problems, and Materials on Bankruptcy at 577 (cited in note 64).

118 Staying orders and injunctions will not prevent swift correction of emergency situations, because even the EPA admits that orders and injunctions are slower than cleanup by the EPA itself. EPA, A Management Review of the Superfund Program at 1-5 (cited in note 19).

11011 USC $\S 362(\mathrm{~b})(5)$.

220 Staying injunctions and administrative orders also gains support from the collective action theory of bankruptcy. According to this theory, the function of bankruptcy is to increase the size of the "pie," the assets available for distribution to creditors (including the EPA), without altering the relative shares of various creditors. Non-bankruptcy law provides the baseline for evaluating each creditor's share of the debtor's assets. See Jackson, The Logic and Limits of Bankruptcy Law at 7-19 (cited in note 32). According to nonbankruptcy law, the EPA-even with its power to secure injunctions and issue administrative orders-is functionally an unsecured creditor; its ability to force the debtor to clean up is dependent on its ability to enforce an injunction or administrative order before other creditors levy on the debtor's property. Exempting injunctions and orders from the bankruptcy stay would alter the relative shares of the EPA and the other creditors by allowing the EPA to enforce fully its injunction or order while granting other unsecured creditors only a pro-rata share of the debtor's unencumbered assets. Since exempting injunctions and orders from the stay would alter the non-bankruptcy shares, the collective action theory of bankruptcy suggests non-exemption. 
money judgments is not excepted from the stay, because "enforcement by a governmental unit of a money judgment would give it preferential treatment to the detriment of all other creditors."121 Similarly, Representative Edwards stated that the exception to the stay "is intended to be given a narrow construction in order to permit governmental units to pursue actions to protect the public health and safety and not to apply to actions by a governmental unit to protect a pecuniary interest in property of the debtor or property of the estate."122

Several courts have interpreted the automatic stay in accordance with this legislative intent. For example, the Eighth Circuit refused to exempt from the stay an injunction brought to enforce Missouri laws relating to grain warehouses, because it concluded that "Missouri's grain laws, although regulatory in nature, primarily relate to the protection of the pecuniary interest in the debtor's property. ..."123 And in United States $v$ Johns-Manville Sales Corp. ${ }^{124}$ the court directly addressed the question of the enforceability of a CERCLA injunction and found that the automatic stay barred enforcement. The court distinguished between injunctions forbidding future releases of hazardous substances, which are barred, and injunctions to remedy prior contamination, which are not. ${ }^{125}$ The court also emphasized that the injunction was merely an alternative to the expenditure of Superfund money and later reimbursement. ${ }^{126}$

The Third Circuit reached the opposite result in Penn Terra $v$ Dept. of Environmental Resources. ${ }^{127}$ Penn Terra involved an injunction relating to the Pennsylvania Clean Streams Law ${ }^{128}$ and the Bituminous Coal Open Pit Mining Conservation Act, ${ }^{129}$ not CERCLA. Although the Penn Terra court allowed enforcement of

121 Bankruptcy Act Amendments, HR Rep No 97-420, 97th Cong, 2d Sess 3 (1982). For a more detailed analysis of the legislative history, see John P. Hennigan, Jr., Accommodating Regulatory Enforcement and Bankruptcy Protection, 59 Am Bankr L J 1, 19-22 (1985). Hennigan also concludes that CERCLA injunctions should be stayed.

${ }^{123} 124$ Cong Rec 11089 (Sept 28, 1978).

123 In re State of Missouri v U.S. Bankr. Court for E.D. of Ark., 647 F2d 768, 776 (8th Cir 1981). A California bankruptcy judge held that the automatic stay prevented California from suspending a debtor's corporate powers on account of non-payment of taxes, because the state's primary motive was "the protection of a pecuniary interest." In re Golden Plan of California, 37 Bankr 167, 170 n 2 (Bankr E D Cal 1984).

12418 ERC 1177 (D NH 1982).

125 Id at 1181.

128 Id at $1178,1181-82$.

327733 F2d 267 (3d Cir 1984).

${ }^{228} 35 \mathrm{~Pa}$ Stat $\S 691.1$ et seq (Purdon 1977 \& Supp 1983).

$12952 \mathrm{~Pa}$ Stat $\S 1396.1$ et seq (Purdon 1966 \& Supp 1983). 
the injunction despite the automatic stay, the court's reasoning is consistent with that in Johns-Manville. The court in Penn Terra admitted that an action "not facially resembling an enforcement of a money judgment" may "achieve in actuality what a money judgment was intended to accomplish," and added that "an important factor in identifying a proceeding as one to enforce a money judgment is whether the remedy would compensate for past wrongful acts resulting in injuries already suffered, or protect against potential future harm."130 Because the primary purpose of CERCLA injunctions is to remedy past releases, this analysis supports treating CERCLA injunctions as proceedings to enforce money judgments, thus subject to the stay. The fact that the EPA can protect against future harm by cleaning up the property itself and petitioning for reimbursement reinforces this conclusion.

Even if the exception to the automatic stay is interpreted to exempt a CERCLA order or injunction, the bankruptcy court still has the power to stay it. As the legislative history makes clear:

The effect of an exception is not to make the action immune from injunction. ... The court has ample other powers to stay actions not covered by the automatic stay. Section $105 \ldots$. grants the power to issue orders necessary or appropriate to carry out the provisions of [the Bankruptcy Code]. . . . By excepting an act or action from the automatic stay, the [Code] simply requires that the trustee move the court into action, rather than requiring the stayed party to request relief from the stay. ${ }^{131}$

Thus, even if CERCLA administrative orders and injunctions are exempted from the automatic stay, the court can and should stay them using its powers under $\S 105 . .^{132}$

\section{CONCLUSION}

The bankruptcy priority of CERCLA reimbursement claims for cleanup of sites contaminated by pre-petition release of hazardous waste presents knotty problems for the courts. Most courts addressing these issues have given such claims administrative priority. That resolution, however, misapprehends both CERCLA and the Bankruptcy Code. Administrative expense priority should be

130 733 F2d at 275-77 (emphasis in original).

131 S Rep No 95-989 at 51 (cited in note 71); see also HR Rep No 95-595 at 342 (cited in note 71).

132 11 USC § $105(a)$. 
granted only to claims resulting from the trustee's post-petition management of the firm's assets. When the release of hazardous substances occurs pre-petition, liability arising out of that release should not receive administrative expense status. This result avoids treating claims based on environmental damage more favorably than those involving personal injury or other torts. Treating reimbursement claims as ordinary unsecured claims, however, still allows the EPA to gather funds from other sources for its cleanup. CERCLA's liability provisions enable the EPA to recover its cleanup costs from subsequent purchasers in a liquidation or from the firm itself after reorganization. In cases where the property is abandoned or excluded from the reorganization plan, the EPA is entitled to the proceeds of the post-cleanup sale of the property through its lien provisions. But the EPA should not be able to circumvent its unsecured status through the use of administrative orders or injunctions requiring cleanup. Such remedies, which operate to enforce a monetary obligation rather than the police power, should be subject to the Bankruptcy Code's automatic stay provisions. 